Warszawskie Studia Pastoralne UKSW

Rok XI 2016 Nr 4(33)

Ks. Piotr Ochotny

\title{
ŹRÓDŁA I FORMY PRZEPOWIADANIA SŁOWA BOŻEGO
}

The sources and forms of speaking God's Word

Przepowiadanie słowa Bożego, które jest kontynuacją zbawczego dzieła i posłannictwa Jezusa Chrystusa, należy od początków Kościoła do podstawowych jego funkcji. W rozumieniu szerokim obejmuje całość kościelnego nauczania, a zatem wypowiedzi Magisterium Kościoła, wykład teologiczny, konferencję religijną, katechezę, kazanie, dialog religijny, utwory pisane itd. Natomiast w rozumieniu wąskim, które odnaleźć można w Kodeksie Prawa Kanonicznego (kan. 762-772) używa się go na określenie teorii i praktyki, odmiennego od katechezy, ustnego sposobu kościelnej posługi słowa, urzeczywistniającego się w dwóch zasadniczych jednostkach: kazaniu i homiliii ${ }^{1}$. W niniejszym artykule omówione zostaną źródła i formy przepowiadania słowa Bożego w rozumieniu wąskim.

\section{1. Źródła przepowiadania słowa Bożego}

„Ponieważ Lud Boży jednoczy się przede wszystkim przez słowo Boga żywego"2 dlatego też Kodeks Prawa Kanonicznego, idąc za wskazaniami Konstytucji dogmatycznej o Objawieniu Bożym ${ }^{3}$, daje priorytet nie doktrynie Kościoła lecz Biblii i stwierdza, że posługa słowa winna opierać się na Piśmie Świętym, Tradycji, liturgii, Nauczycielskim Urzędzie i życiu Kościoła. W oparciu o te źródła należy przedstawić

1 Por. G. Siwek, Przepowiadanie słowa Bożego, w: Leksykon teologii pastoralnej, red. R. Kamiński, W. Przygoda, M. Fijałkowski, Lublin 2006, s. 696.

2 KPK, kan. 762.

3 Zob. Sobór Watykański II, Konstytucja dogmatyczna o Objawieniu Bożym, nr 24 (dalej skrót: KO). 
w „całości i wiernie tajemnicę Chrystusa”4 . Rozwińmy podział źródeł przepowiadania zaproponowany przez nowe prawo.

\section{a. Pismo Święte}

W świetle dokumentów Soboru Watykańskiego II pierwszym i niezastąpionym źródłem przepowiadania słowa Bożego jest Pismo Święte Starego i Nowego Testamentu. Biblia, zawierająca orędzie zbawienia, zajmuje w życiu Kościoła szczególne miejsce. Jest miejscem osobowego spotkania człowieka z objawiającym się Bogiem. Jest także księgą wezwania, ponieważ domaga się od człowieka odpowiedzi, którą jest wiara, pojmowana jako całkowite powierzenie się Bogu, a także jako uległość rozumu i woli ${ }^{5}$. Ta święta księga, wyrosła $\mathrm{z}$ wiary Kościoła, do wiary także chce prowadzić ${ }^{6}$, co zresztą dobitnie oddają słowa pouczenia św. Pawła z Listu do Rzymian: „wiara rodzi się z tego, co się słyszy, tym zaś, co się słyszy, jest słowo Chrystusa" (Rz 10, 17)7. Znajdują one echo w nauczaniu soborowym, które z naciskiem podkreśla, że „Kościół miał zawsze we czci Pisma Boże, podobnie jak samo Ciało Pańskie, skoro zwłaszcza w Liturgii św. nie przestaje brać i podawać wiernym chleb żywota tak ze stołu słowa Bożego, jak i Ciała Chrystusowego. Zawsze uważał i uważa owe Pisma zgodnie z Tradycją świętą, za najwyższe prawidło swej wiary, ponieważ natchnione przez

${ }^{4}$ KPK, kan. 760.

5 Por. H. Simon, Przepowiadanie biblijne, w: Biblia w nauczaniu chrześcijańskim, red. J. Kudasiewicz, Lublin 1991, s. 58.

6 Zob. KO 2; 5.

7 Widoczne jest to już w Starym Testamencie. Lud Boży Starego Przymierza, to qehal Jahwe, zgromadzenie zwołane przez słowo Boże. Grupa niewolników zbiegłych z Egiptu pod wodzą Mojżesza nabiera nowej świadomości dzięki słuchaniu słowa Bożego w przymierzu na Synaju (Wj 19-24). Odnowienie tej świadomości oraz więzi z Bogiem i ludźmi dokonuje się przez słuchanie i przyjęcie Słowa Bożego (2 Krl 2223; Ne 8-10). Podobnie buduje się Kościół Chrystusowy. Pierwsi słuchacze Jezusa to pierwsi członkowie Jego Kościoła. Słowo Boże powoduje także wzrost Kościoła po zmartwychwstaniu Chrystusa, dokonujący się w rytmie wzrostu i rozszerzania się słowa Bożego (Dz 6, 7; 20, 32). Zob. L. Stachowiak, Od «zgromadzenia Jahwe» do Kościoła. Elementy eklezjalne w Starym Testamencie, w: Kościót w świetle Biblii, Lublin 1984, s. 9-20. 
Boga i raz na zawsze utrwalone na piśmie przekazują niezmiennie słowo samego Boga, a w wypowiedziach Proroków i Apostołów pozwala rozbrzmiewać głosowi Ducha Świętego"8.

Nauczanie Soboru Watykańskiego II podkreśla konieczną korelację między słowem a sakramentem oraz mówi o zbawczej obecności Pana tak w słowie, jak i w świętym znaku'. Uprawnione jest zatem mówienie o podwójnym stole lub o dwóch stołach: stole słowa i Ciała Chrystusowego ${ }^{10}$. „Łączą się one ściśle ze sobą przez wspólną im obydwu, choć niejednakową, obecność Chrystusa i wspólne im Jego

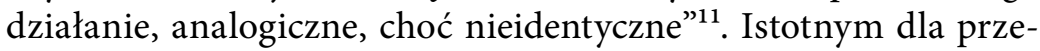
powiadania jest wobec tego stwierdzenie, że Chrystus „jest obecny w swoim słowie, albowiem gdy w Kościele czyta się Pismo św. wówczas On sam mówi”12, „bez przerwy oznajmia swoją Ewangelię”13. Analizując dokumenty soborowe, zwłaszcza Konstytucję dogmatyczna o Objawieniu Bożym oraz Konstytucję o liturgii świętej, można mówić o ponownym „odkryciu Biblii”. Jej prymat w zbawczym posłannictwie Kościoła wyrażony został w wezwaniu, aby „obficiej zastawić dla wiernych stół Słowa Bożego, szerzej otworzyć skarbiec biblijny”14. A na innym miejscu: „Trzeba więc, aby całe nauczanie kościelne, tak jak sama religia chrześcijańska, żywiło się i kierowało Pismem św. Albowiem w księgach świętych Ojciec, który jest w niebie spotyka się miłościwie ze swymi dziećmi i prowadzi z nimi rozmowę. Tak wielka zaś tkwi w słowie Bożym moc i potęga, że jest ono dla Kościoła

\footnotetext{
8 KO 21.

9 Por. K. Rahner, Was ist ein Sakrament? Freiburg 1971, 67-72. Cyt. za H. Simon, Przepowiadanie biblijne, dz. cyt., s. 59.

10 Por. J. Warzecha, Biblia - księga Kościoła, w: Biblia - Sobór - życie. Sympozjum synodalne w Akademii Teologii Katolickiej (17 marca 1992), red. M. Czajkowski, Warszawa 1994, s. 81.

11 Drugi Polski Synod Plenarny. Teksty robocze, Poznań-Warszawa 1991, 1,4.

12 Sobór Watykański II, Konstytucja o liturgii świętej, nr 7 (dalej skrót: KL).

13 Tamże, nr 33.

14 Tamże, nr 51.
} 
podporą i siłą żywotną, a dla synów Kościoła utwierdzeniem wiary, pokarmem duszy oraz źródłem czystym i stałym życia duchowego"15.

\section{b. Tradycja Kościoła}

Drugim źródłem przepowiadania jest Tradycja, przez którą rozumie się sam proces przekazywania objawienia Bożego od jego pierwotnych głosicieli, zwłaszcza od Chrystusa, przez Apostołów, aż po dzień dzisiejszy, jak i samo przekazywane objawienie Boże jako Dobrą Nowinę o zbawieniu oraz rzeczywistość zbawienia ${ }^{16}$. W misji nauczycielskiej Kościoła Pismo św. i Tradycja „ściśle się ze sobą łączą i komunikują. Obydwoje bowiem, wypływając z tego samego źródła Bożego, zrastają się jakoś w jedno i zdążają do tego samego celu"17. Ten sam szacunek należy się zatem Pismu Świętemu jako mowie Boga, utrwalonej na piśmie pod natchnieniem Ducha Świętego, jak i Tradycji, słowie Boga podanym przez Chrystusa i Ducha Świętego Apostołom, a przez nich ich następcom ${ }^{18}$. Konstytucja dogmatyczna o Objawieniu Bożym wyraźnie podkreśla, że Pismo Święte i Tradycja razem tworzą ,jeden święty depozyt słowa Bożego powierzony Kościołowi"19. Same w sobie nie zawierają całej nauki objawionej, lecz stanowią dwa przekaźniki objawienia. Pismo Święte i Tradycja są „jakby zwierciadłem, w którym Kościół pielgrzymujący na ziemi ogłada Boga, od którego wszystko otrzymuje, aż zostanie doprowadzony do oglądania Go twarzą w twarz, takim jakim jest" ${ }^{\text {20 }}$.

\footnotetext{
$15 \mathrm{KO} 21$.

16 Zob. więcej: W. Broński, Recepcja nauczania Kościoła współczesnego na temat Tradycji i dokumentów Urzędu Nauczycielskiego Kościoła jako źródła homilii w przepowiadaniu niedzielnym dla dorosłych «Biblioteki kaznodziejskiej» $i$ «Współczesnej Ambony», „Resovia sacra” 2002, nr 7, s. 135-154.

17 KO 9.

18 Por. Praktyka przepowiadania słowa Bożego. Materiały do nauczania w zakładach teologicznych, t. II, red. L. Kuc, Warszawa, s. 339.

19 KO 10. Zob. także KKK 84.

20 Tamże, nr 7.
} 


\section{c. Urząd Nauczycielski Kościoła}

Konstytucja soborowa Dei Verbum stwierdza, że „zadanie autentycznej interpretacji słowa Bożego, spisanego czy przekazanego przez Tradycję, powierzone zostało samemu tylko żywemu Urzędowi Nauczycielskiemu Kościoła, który autorytatywnie działa w imieniu Jezusa Chrystusa"21. Urząd ten nie stoi ponad słowem Bożym, lecz z woli Bożej temu słowu służy. Funkcję Kościoła wobec objawienia jasno zdefiniował już papież Pius XII w encyklice Humani generis z 12 sierpnia 1950 r.: „Pismo św. winno być wykładane w duchu Kościoła, który przez Chrystusa Pana został ustanowiony jako strażnik i tłumacz (custos et interpres) całego depozytu prawd objawionych" 22 . Głosząc prawdy objawione w sposób autorytatywny i nieomylny, Magisterium Kościoła czerpie z tego depozytu wiary oraz wypowiada się o nim określając jego treść. Sobór Watykański II stwierdza natomiast, że Pismo Święte, Tradycja i Magisterium Kościoła „tak ściśle się ze sobą łączą i zespalają, że jedno bez pozostałych nie może istnieć"23. Pismo św., podstawowe źródło homilii, winno być zatem badane i wykładane pod nadzorem Urzędu Nauczycielskiego, a jego głębszego zrozumienia szukać należy w studium Ojców Kościoła, zarówno wschodnich, jak i zachodnich ${ }^{24}$. Nauczanie zawarte w świadectwach patrystycznych, a także w nauczaniu Kościoła (enuncjacjach Ojca Świętego, nauce soboru, wypowiedziach Stolicy Apostolskiej czy Episkopatu Polski) jest ciągle aktualne i może stanowić inspirację dla posługi słowa.

\section{d. Liturgia}

Przepowiadanie słowa Bożego czerpie swoją treść także z liturgii, która jest źródłem i szczytem całej działalności Kościoła ${ }^{25}$. Stanowi ona „zwiastowanie przedziwnych dzieł Bożych w dziejach zbawienia,

21 KO 10.

${ }^{22}$ Breviarium Fidei III 72.

${ }^{23} \mathrm{KO} 10$.

24 Por. tamże 23.

25 Por. tamże, nr 10. 
czyli w misterium Chrystusowym, które zawsze jest w nas obecne i działa, zwłaszcza w obrzędach liturgicznych"26. Jest kontynuacją dziejów zbawienia, aktualizacją kapłańskiego urzędu Chrystusa oraz działaniem całego Kościoła, wykonywanym pod osłoną znaków ${ }^{27}$. Konstytucja o liturgii świętej zaznacza, że homilia będąca częścią liturgii jest również wydarzeniem zbawczym. Na podstawie tekstów świętych, związanych z wydarzeniami roku liturgicznego, wykłada on tajemnice wiary i zasady życia chrześcijańskiego ${ }^{28}$. Natomiast Ogólne wprowadzenie do Mszału rzymskiego przypomina rozumienie homilii: „Homilia stanowi część liturgii. Jest bardzo zalecana jako nieodzowny czynnik zasilający życie chrześcijańskie. Ma to być albo wykład ujmujący pewien aspekt czytań Pisma św., albo wyjaśnienie innego tekstu, zaczerpniętego z części stałych czy też własnych Mszy z dnia, z uwzględnieniem obchodzonego misterium bądź szczególnych potrzeb słuchaczy"29. Oprócz tekstów biblijnych, źródłem dla homilii są także teksty liturgiczne: Mszy świętej, sakramentów, sakramentaliów i Liturgii Godzin. Tworzywem homiletycznym w ramach samej Mszy świętej mogą być teksty stałe oraz teksty zmienne: teksty okresowe, własne lub wspólne o Świętych, teksty Mszy obrzędowych, Mszy i modlitw w różnych potrzebach, Mszy wotywnych i Mszy za zmarłych $^{30}$.

\footnotetext{
26 Por. KL 35, 2.

27 Zob. S. Czerwik, Wprowadzenie do konstytucji o liturgii świętej, w: Sobór Watykański II, Konstytucje, dekrety, deklaracje, Poznań 1986, s. 28-39.

28 Por. KL 52.

29 Ogólne Wprowadzenie do Mszału Rzymskiego, Kraków-Poznań 1986, nr 41. To rozumienie homilii opiera się na Instrukcji Inter Oecumenici Świętej Kongregacji Obrzędów z 26 września 1964 r. Instrukcja mówi zarazem o czczonej w danej chwili tajemnicy jako źródle jej przepowiadania oraz o tekście świętym. Pojęcie tekstu świętego, według tego dokumentu, oznacza „wyjaśnienie jakiegoś szczegółu z czytań Pisma Świętego lub innego tekstu, który się wybrało z ordinarium lub proprium Mszy danego dnia". Św. Kongregacja Obrzędów, Instrukcja Inter Oecumenici, AAS 1964, nr 56, s. 890, nr 54.

30 Przykłady wykorzystania formularzy mszalnych jako tworzywa w przepowiadaniu homilijnym można znaleźć: W. Głowa, Teksty formularzy mszalnych źródłem przepowiadania homilijnego, w: Digilis me? Pasce. Księga jubileuszowa dedykowana
} 
Zdaniem H. Simona teksty liturgiczne można traktować jako zaktualizowane słowo biblijne w ramach sprawowanego misterium. W przepowiadaniu słowa warto więc dążyć do zespolenia tekstu natchnionego $\mathrm{z}$ tekstem liturgicznym, dzięki czemu oba obszary treściowe znajdą wzajemne wyjaśnienie ${ }^{31}$. Widać to szczególnie w wielkie święta roku liturgicznego. Poszczególne tajemnice zbawienia, zwiastowane w liturgii słowa, powracają w liturgii eucharystycznej, szczególnie w prefacji i wspomnieniach tajemnicy dnia ${ }^{32}$.

\section{e. Doświadczenie życiowe słuchaczy}

Kolejnym źródłem przepowiadania jest doświadczenie życiowe słuchaczy, a więc uwarunkowania historyczno-kulturowe, które kształtują ich mentalność, jak i społeczno-kulturowe, w jakich żyją. Personalistyczny i egzystencjalny rys przepowiadania obecny był już w czasach apostolskich. Dzieje Apostolskie i listy św. Pawła przesiąknięte są reminiscencjami ze zwyczajnego, codziennego życia słuchaczy oraz dotykają najbardziej czułych obszarów ludzkiej egzystencji. Podobnie homilie Ojców Kościoła próbują dać człowiekowi odpowiedź na dręczące go pytania, tak z zakresu życia religijnego jak i codziennego, kościelnego czy społecznego ${ }^{33}$. Dokumenty Kościoła zwracają uwagę na konieczność dokładnego poznania mentalności, obyczajów, okoliczności i uprzedzeń osób, do których się przemawia, a także uwzględnienia ich możliwości percepcji i warunków życia ${ }^{34}$.

biskupowi sandomierskiemu Wacławowi Józefowi Świerzawskiemu na pięćdziesięciolecie święceń kapłańskich 1949-1999, red. S. Czerwik, M. Mierzwa, Sandomierz 1999, s. 346-380.

31 Por. H. Simon, Kaznodziejstwo polskie: zdobycze i niedociagnięcia, „Ateneum Kapłańskie” 1993, nr 121, z. 2-3, s. 253.

32 Por. S. Czerwik, Słowo Boże w liturgii, „Collectanea Theologica” 1967, nr 37, s. 78-79.

33 Por. J. Batkowski, Egzystencjalne warunki człowieka jako tworzywo homilii, „Materiały problemowe” 1975, nr 9/9, s. 111-112.

34 Por. W. Broński, Recepcja nauczania Kościoła współczesnego na temat doświadczenia życiowego słuchaczy jako źródła homilii w przepowiadaniu niedzielnym dla dorosłych «Biblioteki Kaznodziejskiej» $i$ «Współczesnej Ambony», „Roczniki Teologiczne" 2002, t. 49, nr 6, s. 112-113. 
Zrozumienie aktualnych potrzeb ludzkich i poznanie realiów życia słuchaczy sprawia bowiem, że przepowiadanie, oparte na autentycznym słowie Boga, staje się skuteczne i owocne. Należy zatem dążyć, aby w przepowiadaniu te dwie rzeczywistości, Biblia i egzystencjalna sytuacja człowieka, a więc to, co autentycznie Boże, i to, co prawdziwie ludzkie, były zespolone w jedno.

W celu odkrywania związku pomiędzy głoszoną Ewangelią a codziennym życiem ludzi, a także udzielania odpowiedzi na ich żywotne pytania i dostosowania tychże odpowiedzi do mentalności współczesnego pokolenia niezwykle ważnym wydaje się badanie znaków czasu. Samo wyrażenie „znaki czasu” zostało wzięte z Ewangelii (np. Mt 16, 3) i oznacza cuda czynione przez Jezusa jako znaki nadejścia czasów mesjańskich. Papieże Jan XXIII i Paweł VI, a następnie dokumenty soborowe używają tego pojęcia na określenie wydarzeń zachodzących w życiu ludzkości, w których w świetle wiary, dostrzega się wyraz zbawczej woli Bożej i skierowane do człowieka Boże wezwanie $^{35}$. Duch Święty nieustannie ingeruje w dzieje ludzkości, pobudza i oświeca ludzkie serca przez konkretne zjawiska, wydarzenia i procesy, które wymagają konfrontacji z nauką ewangeliczną i zaangażowania chrześcijan ${ }^{36}$. „Kościół - jak naucza Konstytucja duszpasterska o Kościele $w$ świecie współczesnym - zawsze ma obowiązek badać znaki czasów i wyjaśniać je w świetle Ewangelii, tak aby mógł w sposób dostosowany do mentalności każdego pokolenia odpowiadać ludziom na ich odwieczne pytania dotyczące sensu życia obecnego i przyszłego oraz wzajemnego ich stosunku do siebie. Należy zatem poznawać i rozumieć świat, w którym żyjemy, a także jego nieraz dramatyczne oczekiwania, dążenia i właściwości"37.

\footnotetext{
35 Por. A. Zuberbier, Słownik teologiczny, Katowice 1998, s. 691.

36 Por. S. Bielecki, Znaki czasu, art. cyt., s. 923.

37 Sobór Watykański II, Konstytucja duszpasterska o Kościele w świecie współczesnym, nr 4 (dalej skrót: KDK).
} 


\section{Formy przepowiadania}

Przepowiadanie słowa Bożego jest obowiązkiem Kościoła nałożonym przez Zmartwychwstałego Chrystusa (por. Mt 28, 16-20; Mk 16, 15-18) i może przybierać różne formy ${ }^{38}$. Na potrzeby niniejszego artykułu przyjęty został podział form przepowiadania na liturgiczny i pozaliturgiczny. Do liturgicznego należy nauczanie homiletyczne, które polega na „wyjaśnianiu czytań biblijnych oraz sprawowanego obrzędu, wprowadza w aktualizujące się tajemnice zbawcze, szczególnie przygotowuje do uczestnictwa w sakramentach i zawiera konkretne, wynikające $z$ tego faktu zastosowania życiowe"39. Do pozaliturgicznego zaliczyć można kazania i konferencje.

\section{a. Liturgiczna forma przepowiadania słowa Bożego: homilia}

Homilia, będąca integralną częścią liturgii i uobecnieniem słów biblijnych w każdorazowej sytuacji Kościoła, jest najważniejszą i najskuteczniejszą formą przepowiadania słowa Bożego. Podkreśla to wyraźnie Konstytucja o liturgii świętej, w której czytamy: „jako część samej liturgii zaleca się bardzo homilię, w której w ciągu roku liturgicznego, na podstawie tekstów świętych, wykłada się tajemnice wiary i zasady życia chrześcijańskiego" " . „Homilia - według definicji ks. Z. Adamka - (od greckiego słowa homilein - rozmawiam, wyjaśniam) to wyjaśnianie jakiegoś szczegółu z czytań Pisma św. lub innego tekstu (z ordinarium lub proprium) sprawowanego obrzędu liturgicznego, w którym to wyjaśnieniu na podstawie tekstów świętych wykłada się tajemnice wiary i zasady życia chrześcijańskiego"41. W zaproponowanej definicji można wskazać na trzy istotne elementy homilii. Pierwszym z nich jest element biblijny. Nauczanie homiletyczne w możliwie największym stopniu swą treść winno czerpać

\footnotetext{
38 Por. L. Szewczyk, Odnowa przepowiadania słowa Bożego w (archi)diecezji katowickiej po Soborze Watykańskim II, Katowice 2009, s. 1.

39 Por. M. Brzozowski, Przepowiadanie Słowa Bożego, w: Być chrześcijaninem, red. M. Rusecki, Lublin 2003, s. 434.

40 Por. KL 52.

41 Z. Adamek, Homiletyka, Tarnów 1992, s. 130.
} 
z tekstów biblijnych. II Polski Synod Plenarny słusznie zauważa, że "głównym niedomaganiem homilii jest brak biblijności. Kaznodzieje bowiem nie zawsze potrafią wiernie i solidnie ukazywać orędzie czytań, nie dostrzegając ich wzajemnego związku"42. Drugi - to element egzystencjalny. Głosząc w homilii treści zbawcze, kaznodzieja winien uwzględnić aktualną sytuację egzystencjalną ludzi. Ostatni element - liturgiczny - polega na nieustannym liczeniu się z obecnością Trójjedynego Boga, działającego w zgromadzeniu liturgicznym, a także odnalezieniu się w żywej relacji do Ojca, którego wielbimy przez Jezusa Chrystusa w Duchu Świętym ${ }^{43}$. Dla podkreślenia jedności dwóch stołów, słowa i Eucharystii, zaleca się, aby homilię głosił przewodniczący liturgii. Przepowiadający homilię jest bowiem zawsze znakiem pierwszego i prawdziwego słuchacza słowa Bożego, który swym przepowiadaniem wypowiada zbawczo-kultyczny dia$\log \mathrm{z}$ mszalno-biblijnym słowem Boga w kontekście życia i celebrowanej Eucharystii ${ }^{44}$. Można zatem powiedzieć, że przepowiadanie typu homilijnego to proklamacja ekonomii zbawienia, która swoją treść czerpie przede wszystkim z tekstów Pisma Świętego, a dokonuje się w kontekście liturgii i z uwzględnieniem aktualnych potrzeb słuchaczy.

G. Siwek wskazuje, że homilia pełni również funkcję ewangelizacyjną. Będąc spoiwem między liturgią słowa a liturgią Eucharystii, ukazuje ona związek między przepowiadaniem i słuchaniem a tajemnicą eucharystyczną, czyli pomiędzy słowem, Ofiarą i współofiarowaniem $^{45}$. Homilia ewangelizuje wspólnotę eucharystyczną poprzez nieustanne pogłębianie naszego rozumienia i przeżywania Eucharystii. Kodeks Prawa Kanonicznego nakazuje głoszenie homilii we wszystkich Mszach Świętych odprawianych z udziałem

\footnotetext{
42 Drugi Polski Synod Plenarny..., dz. cyt., I, 7.

43 E. Staniek, Z kaznodziejskiego warsztatu, Kraków 1997, s. 14-15.

44 Por. Eucharystia w duszpasterstwie, red. A. Szafrański, Lublin 1977, s. 140. Zob. więcej o cechach homilii w świetle nauki Soboru Watykańskiego II: W. Przyczyna, Przepowiadanie w liturgii. Cechy posoborowej homilii, „Ateneum Kapłańskie” 1996, nr 522, s. 179-186.

45 Zob. G. Siwek, Ewangelizacyjna funkcja homilii, „Homo Dei” 1993, nr 62, s. 84-97.
} 
ludu w niedziele i święta. Zaleca również homilię w dni powszednie, zwłaszcza w okresie adwentu i wielkiego postu oraz z okazji szczególnych wydarzeñ ${ }^{46}$. Zachęca się również do głoszenia homilii przy sprawowaniu sakramentów, gdyż homilia najwłaściwiej wprowadza w sprawowany sakrament, pogłębia jego misteryjną treść, daje tło biblijne, eklezjalne oraz uwzględnia aktualną sytuację uczestniczących w kontekście ekonomii zbawczej Boga. Jak można przeczytać w Dekrecie o posłudze i życiu kapłanów: „głoszenie słowa wymagane jest dla samej posługi sakramentów, ponieważ są to sakramenty wiary, która rodzi się ze słowa i nim się karmi" ${ }^{47}$. To właśnie homilia pozwala zrozumieć odniesienie takich sakramentów, jak chrzest, namaszczenie chorych, święcenia kapłańskie, małżeństwo do Paschy Chrystusa celebrowanej w Eucharystii. Pozostawia ponadto miejsce na adaptację tekstów biblijnych i liturgicznych do konkretnego miejsca, czasu i ludzi ${ }^{48}$. Na szczególną uwagę zasługują homilię wygłaszane w czasie obrzędów pogrzebowych. Wypełnienie chrześcijańskiego obowiązku pogrzebania ciała ludzkiego bardzo często staje się jedyną okazją spotkania ze słowem Bożym dla wielu ochrzczonych, lecz niepraktykujących i obojętnych ${ }^{49}$.

\section{b. Pozaliturgiczne formy przepowiadania słowa Bożego: kazania i konferencje}

Dokumenty soborowe, a także Kodeks Prawa Kanonicznego podkreślają, że podobnie jak liturgia nie wyczerpuje całej działalności Kościoła, tak związana z nią ściśle homilia nie wyczerpuje również całego zakresu przepowiadania ${ }^{50}$. Obok liturgicznej (homilijnej) formy przepowiadania słowa Bożego istnieje jeszcze forma pozaliturgiczna, obejmująca kazania i konferencje. Według Leksykonu Teologii Pastoralnej kazanie jest jednostką „,ustnego, publicznego, oficjalnego i zo-

\footnotetext{
46 Por. KPK, kan. 767.

47 Sobór Watykański II, Dekret o posłudze i życiu kapłanów, nr 4.

48 Por. Eucharystia $w$ duszpasterstwie, dz. cyt., s. 126.

49 Por. Praktyka przepowiadania słowa..., dz. cyt., s. 231.

50 Por. KDF 19; KPK, kan. 761.
} 
bowiązującego przepowiadania słowa Bożego, przez przedstawiciela Kościoła, w celu doprowadzenia do wiary, nawrócenia i wspólnoty, dokonującego się poza kontekstem liturgicznym" ${ }^{51}$. Wskazuje się następujące rodzaje kazań: pasyjne, nowennowe i seryjne (misyjne i rekolekcyjne $)^{52}$. Właśnie na te ostatnie formy przekazu słowa Bożego Kodeks Prawa Kanonicznego zwraca szczególną uwagę i zaleca duszpasterzom, aby w pewnych okresach je organizowali ${ }^{53}$. Rekolekcje ogólnoparafialne, według G. Siwka, są „akcją duszpasterską, której celem jest kontynuacja, umacnianie i pogłębianie życia chrześcijańskiego odnowionego, względnie ożywionego przez misje ludowe czy też rekolekcje ewangelizacyjne" ${ }^{54}$. Podobnie określa je J. Kołodziejczyk jako „działalność duszpasterską Kościoła, która realizuje się poprzez słowo i sakrament i zmierza do odnowy chrześcijańskiego stylu życia w wiernych oraz budowania Kościoła i lepszego świata przez przepojenie duchem ewangelicznym spraw doczesnych"55. Celem każdych rekolekcji jest nawrócenie zarówno w wymiarze moralnym, jak i religijnym, „odnowa wiary i życia chrześcijańskiego” ${ }^{56}$, a ich widzialnym owocem powinno być pozyskanie ludzi niewierzących, obojętnych i zaniedbanych pod względem religijnym.

Rekolekcje, przeprowadzane w okresie adwentowym i wielkanocnym, powinny odkrywać zbawcze znaczenie Narodzenia Pańskiego i Misterium Paschalnego i przyczyniać się do głębszego rozumienia Tajemnicy Jezusa Chrystusa, a tym samym odnawiać w wiernych Jego obecność $c^{57}$. Z kerygmatem rekolekcyjnym powinno się docierać do wszystkich wiernych, ale mogą być one także organizowane dla

\footnotetext{
51 G. Siwek, Kazanie, art. cyt., s. 366.

52 Zob. G. Siwek, Przepowiadanie słowa Bożego, w: Teologia pastoralna, t. II, red.

R. Kamiński, Lublin 2002, s. 170-174.

${ }^{53} \mathrm{KPK}, \mathrm{kan} .770$.

${ }^{54}$ G. Siwek, Rekolekcje dla dorostych, Kraków 1999, s. 5.

55 J. Kołodziejczyk, Kazania misyjne i rekolekcyjne, „Materiały Problemowe” 1988, nr 2, s. 111.

${ }^{56}$ Jan Paweł II, Redemptoris missio, nr 2.

57 Por. H. Simon, Teologiczne podstawy rekolekcji, „Ateneum Kapłańskie” 1985, nr 104, s. 392.
} 
różnych grup, stanów i zawodów. Według tradycyjnego podziału zwykło się wyróżniać trzy typy rekolekcji: otwarte, półzamknięte i zamknięte. Rekolekcje otwarte, których przykładem są tradycyjne rekolekcje parafialne, charakteryzują się tym, że ich uczestnicy nie przerywają swoich codziennych obowiązków, a na nauki rekolekcyjne udają się do kościoła i uczestniczą w ciągu dnia zazwyczaj w jednej konferencji. Rekolekcje półzamknięte organizowane są dla mniejszych grup w specjalnie wyznaczonym na ten cel miejscu, w którym rekolektanci przeżywają dzień rekolekcyjny (na noc wracają do swych domów). Klasyczną formę rekolekcji w sensie ścisłym są rekolekcje zamknięte. Rekolektanci zamieszkują w domu rekolekcyjnym i wyłączają się z codziennych zajęć, aby pod kierunkiem rekolekcjonisty pogłębić jakiś aspekt życia wiarą w klimacie ciszy i modlitewnego skupienia $^{58}$.

Szczególnie istotną formą przepowiadania są misje święte, których celem jest ogólna mobilizacja parafii, miasta czy regionu do ożywienia i pogłębienia życia chrześcijańskiego ${ }^{59}$. Odnowa ta powinna być fundamentalna (dotycząca samych podstaw życia chrześcijańskiego), wspólnotowa (dotycząca interpersonalnych relacji wypływających z faktu przyjęcia chrztu) i apostolska (zmierzająca do budowy chrześcijańskiej wspólnoty apostolskiej przez przysposobienie adresatów misji do apostolstwa i tworzenie okazji do konkretnych działań apostolskich) ${ }^{60}$. Struktura poszczególnych kazań i konferencji misyjnych oraz całej serii powinna uwzględniać trzy fazy: (1) nakreślenie aktualnej sytuacji egzystencjalnej słuchaczy, (2) ukazanie dzieła zbawienia, które aktualnie dokonuje Chrystus mocą Ducha Świętego w Kościele i przez Kościól, (3) wezwanie do wiary i nawrócenia przez skorzystanie z sakramentu pokuty i pojednania oraz wezwanie do odnowy życia chrześcijańskiego ${ }^{61}$.

\footnotetext{
58 Por. G. Siwek, Rekolekcje, art. cyt., s. 728.

59 Por. E. Staniek, Z kaznodziejskiego warsztatu, dz. cyt., s. 127.

60 Por. M. Brzozowski, Misje parafialne - forma nadzwyczajnego duszpasterstwa, „Ateneum Kapłańskie” 1985, nr 105, s. 4.

61 Por. J. Krzemiński, Vademecum misjonarza rekolekcjonisty, Kraków 1998, s. 12.
} 
Ostatnią formą pozaliturgicznego przepowiadania są konferencje, głoszone między innymi podczas dni skupienia, w ramach różnych nabożeństw (np. różańca czy majówki) czy rekolekcji. Konferencja różni się od kazania czy homilii sposobem ujęcia tematu oraz długością. Konferencje są zwykle dłuższe (30-45 min.) i zawierają konkretne zastosowanie życiowe. Zwraca się w nich uwagę na racjonalne uzasadnienie głoszonych prawd, stąd też opracowanie tematu zbliża je czasami do wykładu naukowego. Przedmiotem konferencji są bardzo często sprawy, na temat których nie można znaleźć wprost uzasadnienia w samym Objawieniu ${ }^{62}$.

Podsumowując, należy zauważyć, że dokumenty Soboru Watykańskiego II i posoborowe nauczanie Kościoła poświęcają wiele miejsca źródłom i formom kościelnego przepowiadania. Historia i współczesność świadczą, że jednostki przepowiadania mogą przyjmować różne formy. Podstawową jednak formą jest zawsze homilia, dla której pierwszym i niezastąpionym źródłem jest Pismo Święte Starego i Nowego Testamentu. W oparciu o nie, a także roztropnie korzystając z Tradycji świętej, pism patrystycznych, tekstów liturgicznych, dokumentów Magisterium Kościoła, czasopism teologicznych, a także bazując na doświadczeniu życiowym swoim i cudzym, w Kościele głoszona jest ekonomia zbawienia, a przede wszystkim osoba Jezusa Chrystusa.

\section{Streszczenie:}

Przepowiadanie słowa Bożego jest kontynuacją zbawczego dzieła Chrystusa. Od samego początku Kościoła stanowi jedną z trzech podstawowych jego funkcji. Dokumenty Soboru Watykańskiego II i posoborowe nauczanie Kościoła poświęcają wiele miejsca źródłom i formom kościelnego przepowiadania. Historia i współczesność świadczą, że jednostki przepowiadania mogą przyjmować różne formy. Podstawową jednak formą jest zawsze homilia, dla której pierwszym i niezastąpionym źródłem jest Pismo Święte Starego i Nowego Testamentu.

62 Por. Z. Adamek, Homiletyka, dz. cyt., s. 131. 


\section{Summary:}

Speaking God's Word is a continuation of Jesus's mission of salvation. It is one of three basic functions of the Church from Her beginning. Documents of the Second Vatican Council and following Church's teaching place a great deal of importance on the sources and forms of expressing the God's Word. History and contemporary times show that speaking can adopt various forms. However, the most basic form is always homily, for which Holy Bible Old and New Testament are the first and an irreplaceable source.

Słowa kluczowe: Przepowiadanie słowa Bożego, źródła i formy, homilia, kazanie, Pismo Święte, Tradycja, liturgia.

Key words: Speaking God's Word, sources and forms, homily, sermon, Holy Bible, Tradition, liturgy

\section{Biogram:}

Piotr Ochotny - mgr teologii, doktorant na Wydziale Filozofii Chrześcijańskiej i Wydziale Teologicznym Uniwersytetu kardynała Stefana Wyszyńskiego w Warszawie, nauczyciel podstaw filozofii w Katolickim Liceum Ogólnokształcącym im. Bł. Ks. R. Archutowskiego w Warszawie. Zainteresowania badawcze dotyczą problematyki tożsamości osobowej i granic ingerencji medycznych, relacji między naukami przyrodniczymi a teologią, a także zastosowania podejścia systemowego w programowaniu duszpasterskim.

\section{Bibliografia:}

Adamek Z., Homiletyka, Tarnów 1992.

Batkowski J., Egzystencjalne warunki człowieka jako tworzywo homilii, „Materiały problemowe” 1975, nr 9.

Bielecki S., Znaki czasu, w: Leksykon teologii pastoralnej, red. R. Kamiński, W. Przygoda, M. Fijałkowski, Lublin 2006.

Broński W., Recepcja nauczania Kościoła współczesnego na temat Tradycji i dokumentów Urzędu Nauczycielskiego Kościoła jako źródła homilii w przepowiadaniu niedzielnym dla dorostych «Biblioteki kaznodziejskiej» $i$ «Wspótczesnej Ambony», „Resovia sacra” 7(2002).

Brzozowski M., Misje parafialne - forma nadzwyczajnego duszpasterstwa, „Ateneum Kapłańskie” 1985, nr 105.

Brzozowski M., Przepowiadanie Słowa Bożego, w: Być chrześcijaninem, red. M. Rusecki, Lublin 2003. 
Czerwik S., Słowo Boże w liturgii, „Collectanea Theologica” 1967, nr 37.

Czerwik S., Wprowadzenie do konstytucji o liturgii świętej, w: Sobór Watykański II, Konstytucje, dekrety, deklaracje, Poznań 1986.

Drugi Polski Synod Plenarny, Teksty robocze, Poznań-Warszawa 1991.

Eucharystia w duszpasterstwie, red. A. Szafrański, Lublin 1977.

Głowa W., Teksty formularzy mszalnych źródłem przepowiadania homilijnego, w: Digilis me? Pasce. Księga jubileuszowa dedykowana biskupowi sandomierskiemu Wacławowi Józefowi Świerzawskiemu na pięćdziesięciolecie święceń kapłańskich 1949-1999, red. S. Czerwik, M. Mierzwa, Sandomierz 1999.

Simon H., Przepowiadanie biblijne, w: Biblia w nauczaniu chrześcijańskim, red. J. Kudasiewicz, Lublin 1991.

Jan Paweł II, Redemptoris mission, AAS 1991, nr 83, s. 249-340.

Rahner K., Was ist ein Sakrament?, Freiburg 1971.

Katechizm Kościoła Katolickiego, Città del Vaticano 1992.

Kodeks Prawa Kanonicznego, Città del Vaticano 1983.

Kołodziejczyk J., Kazania misyjne i rekolekcyjne, „Materiały Problemowe” 1988, nr 20.

Krzemiński J., Vademecum misjonarza rekolekcjonisty, Kraków 1998.

Ogólne Wprowadzenie do Mszału Rzymskiego, Kraków-Poznań 1986.

Praktyka przepowiadania słowa Bożego. Materiały do nauczania w zakładach teologicznych, t. II, red. L. Kuc, Warszawa 1973.

Przyczyna W., Przepowiadanie w liturgii. Cechy posoborowej homilii, „Ateneum Kapłańskie" 1996, nr 522.

Simon H., Kaznodziejstwo polskie: zdobycze i niedociagnięcia, „Ateneum Kapłańskie" 1993, nr 121.

Simon H., Teologiczne podstawy rekolekcji, „Ateneum Kapłańskie” 1985, nr 104.s. 392.

Siwek G., Ewangelizacyjna funkcja homilii, „Homo Dei” 1993, nr 62.

Siwek G., Kazanie, Leksykon teologii pastoralnej, red. R. Kamiński, W. Przygoda, M. Fijałkowski, Lublin 2006.

Siwek G., Przepowiadanie słowa Bożego, w: Teologia pastoralna, t. II, red. R. Kamiński, Lublin 2002.

Siwek G., Przepowiadanie słowa Bożego, w: Leksykon teologii pastoralnej, red. R. Kamiński, W. Przygoda, M. Fijałkowski, Lublin 2006.

Siwek G., Rekolekcje dla dorostych, Kraków 1999.

Siwek G., Rekolekcje, w: Leksykon teologii pastoralnej, red. R. Kamiński, W. Przygoda, M. Fijałkowski, Lublin 2006. 
Sobór Watykański II, Dekret o posłudze i życiu kapłanów Presbyterorum ordinis (7 XII 1965), AAS 1966, nr 58.

Sobór Watykański II, Konstytucja dogmatyczna o Objawieniu Bożym Dei Verbum (18 XI 1965), AAS 1965, nr 58.

Sobór Watykański II, Konstytucja duszpasterska o Kościele w świecie współczesnym Gaudium et spes (7 XII 1965), AAS 1966, nr 58.

Sobór Watykański II, Konstytucja o liturgii świętej Sacrosanctum Concilium (4 XII 1963), AAS 1964, nr 56.

Stachowiak L., Od «zgromadzenia Jahwe» do Kościoła. Elementy eklezjalne w Starym Testamencie, w: Kościół w świetle Biblii, Lublin 1984.

Staniek E., Z kaznodziejskiego warsztatu, Kraków 1997.

Św. Kongregacja Obrzędów, Instrukcja Inter Oecumenici, AAS 1964, nr 56. Szewczyk L., Odnowa przepowiadania słowa Bożego w (archi)diecezji katowickiej po Soborze Watykańskim II, Katowice 2009.

Warzecha J., Biblia - ksiegga Kościoła, w: Biblia - Sobór - życie. Sympozjum synodalne w Akademii Teologii Katolickiej (17 marca 1992), red. M. Czajkowski, Warszawa 1994.

Zuberbier A., Słownik teologiczny, Katowice 1998. 